\title{
City image based on mental maps - the case study of Szczecin (Poland)
}

\begin{abstract}
Perception of space is an especially important part of research on urban fabric. The perception of a city is strongly correlated not only with a specific time and place but, first and foremost, with surveyed populations who, apart from having varying demographic features, frequently represent disparate community and cultural profiles.

The objective of this study was to assess how the urban space of Szczecin (Poland) is perceived by its inhabitants and to ascertain the relations between various image elements. The example of Szczecin appears to be interesting, in as much as it is a peripheral city of a cross-border region with a historically and culturally diverse local community. The presented research used a method of analysing mental (image) maps based on the methodology proposed by Kevin Lynch (1960) and modified by the authors to incorporate in-depth interviews. Individual respondents' views were used to create a synthetic image of the city.
\end{abstract}

Keywords

City image $\cdot$ mental maps $\cdot$ space perception $\cdot$ Szczecin $\bullet$ Poland

(๑) University of Warsaw - Faculty of Geography and Regional Studies
Barbara Osóch,

Anna Czaplińska

Human Geography and Spatial Organization

Unit Institute of Socio-Economic Geography and

Spatial Management, Faculty of Geosciences,

University of Szczecin, Poland

e-mail: anna.czaplinska@usz.edu.pl;

barbara.osoch@usz.edu.pl

Received: 23 May 2018

Accepted: 8 March 2019
Introduction

The image of a city is an outcome of individuals' knowledge, experience, emotions and external stimuli that determine the process occurring between the city and the observer. It is the city as the actual passive side of the relation in question that suggests the identification, configuration and interactions between all elements of the urban space, whereas the observer subjectively, often subconsciously, chooses, hierarchises and assigns meanings to what they see. The observer's choices can be determined by demographic features, inter alia by age, hence city images developed by observers of different ages may differ significantly. Every individual creates his or her own image but the images are usually consistent within homogenous groups (Lynch 1960).

When analysing mental maps, geographers and other researchers representing the broadly understood spatial sciences try to connect the map contents with the properties or organisation of the space (Harvey 1973; Lisowski 2003; Liszewski 2005; Gendziwił 2009). The statement of Błahut (2013) should be considered relevant in this context. He stated that "a mental map is an outcome of conceptualisation of space, places, buildings and other features and their interrelations through specific categories of memory and imagination, achieved through sensorimotor and emotional experiences. Mental maps can therefore be effectively learned and explored by, on the one hand, collecting drawings that show the spatial relations, including the geographical ones, and, on the other, by collecting associations and metaphors which carry specific contents and meanings".

The example of the examined harbour city of Szczecin (Poland) may be considered as a local case but of international significance. There are at least a few premises confirming this statement. Szczecin has dynamically changed its territorial affiliation from medieval times. It received city rights in 1243 , belonging then to the main cities of the Hanseatic League and the Pomeranian Duchy (Kozińska, Słomiński \& Solecki 2010). After the Thirty Years War, Szczecin was ruled from 1648 by Sweden which in 1720 lost the city to Prussia. During the Napoleonic wars, it was occupied by the French. The nineteenth century was the period of industrial development (primarily shipbuilding), rail transport and - following the abolition of the status of the fortress in 1873 - the dynamic expansion of the city. In 1939 , the Grand City of Szczecin was created by the resolution of the German government, and became the third largest city of the Reich. In April 1945, Soviet troops entered the city, and in July 1945, Szczecin had already been taken over by Polish authorities (Kozłowski \& Krzywicki 1988).

The geographical location of Szczecin, the third largest city in Poland - situated in the border area, a great distance from the capital, Warsaw, and close to the Baltic Sea, accessible by the navigable Odra (also known as Oder) and the Szczecin Lagoon - has made it an economic centre of the region, affecting the German border areas. Both the Polish and German parts of the region are situated outside the main areas of concentration of population and capital of their countries; in addition, Szczecin is surrounded by areas with a clear depopulation tendency. Poland's accession to the European Union and to the Schengen Agreement opened new development opportunities to Szczecin. It is better accessible from areas located to the west than to the east of the city. For this reason, it can avail of the opportunities 
provided by its location in the wider European spatial layout. Its border location means that, much closer than Warsaw, there are three major metropolitan cities in the vicinity - Berlin, Hamburg and the Øresund region (Copenhagen-Malmö). The connection of Szczecin with the European motorway system and the shortest Polish ferry connection with Scandinavia gives much better transport accessibility to Western Europe and Scandinavia than to the rest of the country. One of the pillars of the city's development strategy (Project Floating Garden 2050) is the revival of water tourism, including sailing. This is possible due to the water areas that dominate in the city landscape, occupying almost $25 \%$ of its area, and distinguishing itself from other administrative units in Poland. In addition, the city is surrounded by three large forest complexes, which through the municipal forests, the system of landscape parks and urban green areas enter the city area. Hence the colloquial term for Szczecin as a "green city" (Szczecin. Raport o stanie miasta 2014 [Report on the state of the city 2014]). The city is a tourist centre with a large number of monuments. It is an academic and cultural centre. The location of the Headquarters of the Multinational Corps Northeast Corps (MNC NE), the international NATO North Atlantic Treaty Organization, consisting of formations stationed in Denmark, Germany and Poland, also provides evidence of multinationality.

The image of the city, created on the basis of mental maps, allows us to determine urban landmarks that are viewed as most typical by the surveyed group, as well as places that have been ignored in their notion of the city. This may in turn become a premise for further work on the city space, e.g. with regard to place branding or investment attractiveness, or for research on the applicability of geographical education concerning the sense of direction in space, and information on the neighbourhood

This work presents the methodology used for the research, the results of interviews and sketched mental maps. The summary discusses the research results and the conclusions drawn from them.

\section{Methods and the study area}

The objective of this study is to assess how the urban space of Szczecin is perceived by its young inhabitants and to ascertain the relations between various elements of the images they produce. The following research assumptions were made:

- the age and nationality of respondents determine their notion of Szczecin;

- a homogeneity and a cohesion of the vision of Szczecin appear simultaneously in the maps and questionnaire forms completed by respondents;

- natural elements that dominate in the landscape of Szczecin (e.g. the level of coverage of water areas) are visualised on mental maps.

The example of Szczecin was a convenient choice (convenience sampling), but as a large harbour city, located peripherally in the border area with a historically and culturally diverse community, it provided the opportunity to reach a multinational youth group. In order to achieve the set goal at the school level, an educational institution was sought, whose community would be of an international character. Finally, the research was directed to middle and high school students from leading Szczecin educational institutions with a long tradition - a private school of the Szczecin International School Team joining children of NATO soldiers and international entrepreneurs operating in Szczecin and the Construction School Casimir the Great. The research was carried out in the form of a crosssectional direct study, from November 2017 to January 2018.

The study consisted of two parts that students did during the one-hour classes: on one side of a sheet of paper pupils drew mental maps of the city of Szczecin, on the second side they filled out the anonymous questionnaire form titled "Szczecin through the eyes of international residents". The desire to verify the conscientiousness of the respondents carrying out the task was an idea which motivated the authors to apply two research methods simultaneously. The empirical part involved a total of 224 students, of whom 167 (74.6\%) were Poles and 57 (25.4\%) were foreigners. Most of the foreign students came from Germany $(8.5 \%)$, Denmark $(3.6 \%)$, Lithuania $(2.2 \%)$, Estonia $(1.8 \%)$ and the United States $(1.8 \%)$. In terms of gender structure, $43.3 \%$ of the respondents were female. The age of the participants ranged from 12 to 19 , the average being 17 .

In the first part of the study, the method of mental maps was applied to assess the perception of the urban space of Szczecin (Tuan 1975; Ley 2000; Gregory 2009). It may also be referred to as a sketch map - Marshall 2017, cognitive map - Kaplan 1973, Kitchin 1994, Downs, Stea 1973, 1977, Tolman 1948, 1995, Kuipers 1982, Hauzinski 2011. Both the perception of space and the method used for its assessment are defined as "the model of the environment built with time in the brain of the individual" by Philip Sarre in E. Graham (1976), or by Goodey and White in E. Graham (1976), as "the scenery in our head depicting the outside world".

A total of 140 maps were selected for analysis; the remaining sketches were indecipherable or incomplete (e.g. signed only), probably because of the participants' unwillingness or lack of predisposition (e.g. poor imagination) to fulfil the task (Nawrocki 2015). The respondents were asked to make a sketch map of Szczecin from their respective perspectives, without receiving additional suggestions from the researchers (Figure 1). In the test procedure, the assumptions of the point grading method were adopted, whereby each existing point of the selected sketch element was assigned a point. On the basis of data aggregation, cartograms were made in the Corel Draw graphics program.

The second part is the questionnaire (Punch 2005), consisting of 13 questions, including 5 metric questions. The questions were open and closed with one and multiple choices. It was assumed that the image of the city would be pre-formed in their minds by framing questions about their first associations of Szczecin, favourite places of leisure, places they avoid, sought-after forms of leisure, quality of life in the city, as well as about verbal communication levels in different environments of the urban fabric. The questionnaire asked about five characteristics of the respondents: nationality, gender, age, place of residence and length of stay in Szczecin.

\section{Szczecin in mental maps}

The main part of the study was based on the theoretical principles formulated by Kevin Lynch (1960). He proposed that community mental maps consist of five elements: paths, edges, districts, nodes and landmarks.

The above categories and the links between them can be used to create a brief and countable, and thus objective description of the image of the city, and to compare it with other cities. The said elements are material in character and are easily discernible in the space, thus contributing to the imageability of the area, but they do not allow for, inter alia, the function or history of the settlement unit. This seems to be not very relevant in this particular study, however, because it attempted to answer the following questions: (1) which (of the above-mentioned) elements form the image of the city? (2) which distinctive features of the city are recognisable and to what extent? (3) are the identifiable elements integrated so as to form spatial continuity that could enable the presentation of the overall image of the city?

As pointed out by Lynch (1960) and confirmed by the presented research, roads are the dominant element on mental maps. Landmarks and functional areas (districts) are also among 


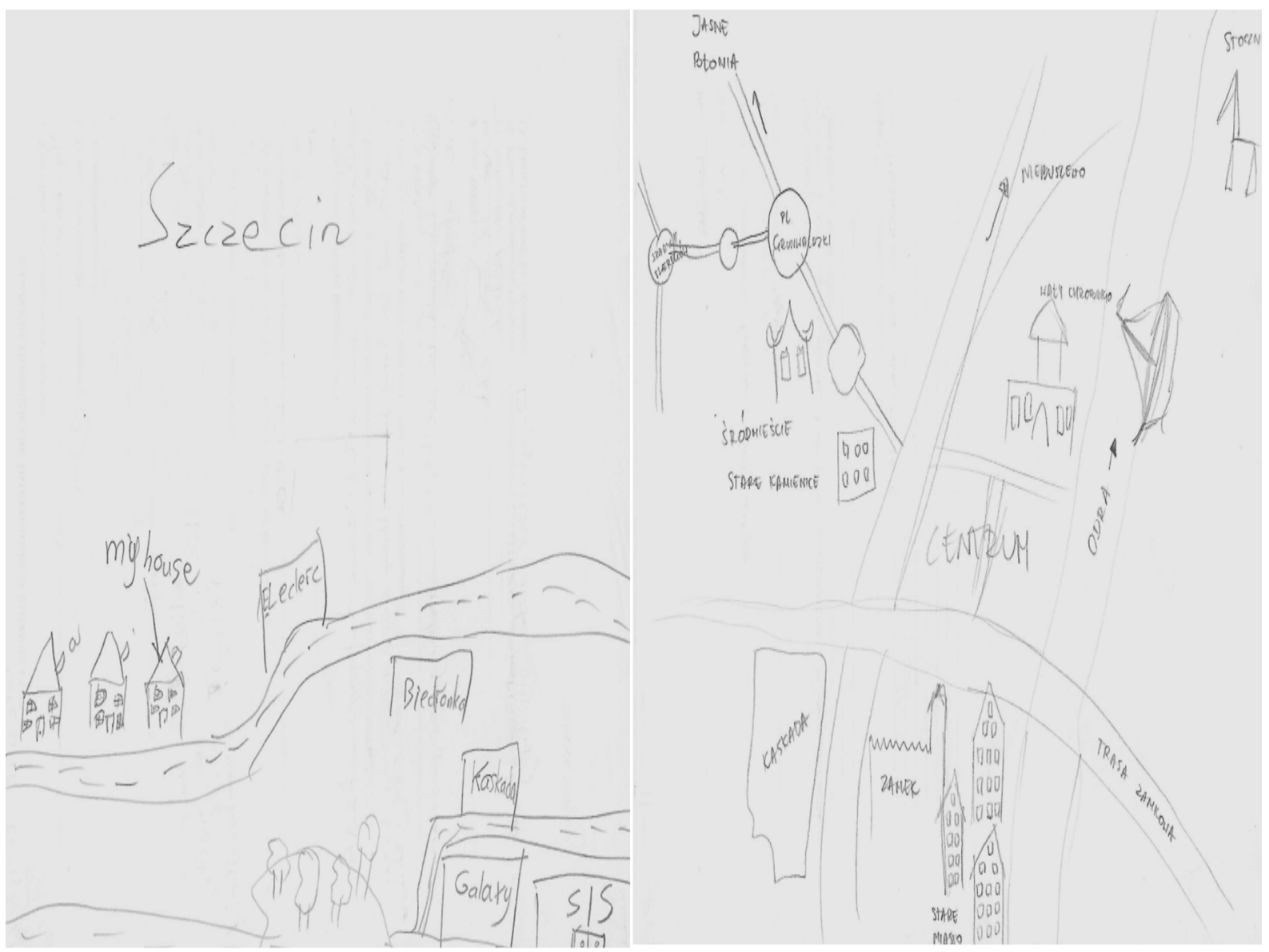

Figure 1. Selected examples of mental maps made by participants aged: (a) 12 years; (b) 18 years. Source: students' work.

the most commonly chosen elements to describe the city, while edges appeared least frequently in the sketches. The elements were combined differently. No combination of all five elements was found on any of the maps. Three of the elements were chosen most often $(40.6 \%)$, with the most popular combination being one that included roads, districts and landmarks (18.6\%). A combination of two elements was the second most popular $(28.1 \%)$. In this case, most sketches $(16 \%)$ featured roads and landmarks. The other maps combined four elements $(15.7 \%)$ or consisted of one element only (14.9), mostly roads $(5.7 \%)$ or landmarks (4.3\%).

The linear elements on the mental maps of Szczecin are only dominant on account of the city's most important feature the Oder River, which flows through the central estates of the city and divides them into two parts: the left bank and the right bank (Strategy Office of the City of Szczecin 2014). The river can therefore be partly considered as an edge. Being the most frequently drawn element of the city, the Oder River appeared as a linear feature on $51.4 \%$ of the mental maps. Among the roads sketched on the mental maps, the following were less frequent $(6.4 \%$ each): Castle Route - one of the most important arteries connecting the left bank with the right one and running through the historic centre of Szczecin, and Piast Boulevard - one of the most popular places of recreation in the city at the Oder. The Szczecin Terrace (also known as the Chrobry Embankment or the Haken Terrace; in Polish: Wały Chrobrego; in German: Hakenterasse), a 500-metre-long viewing terrace along the Oder embankment, appeared as a road in only $3.6 \%$ of the sketches. It is worth noting that this very feature of Szczecin appeared in the sketches not only as a linear element but also as a functional area (district) and as a landmark. In total, it appeared in $11.4 \%$ of the sketches.

Other linear elements appeared on few mental maps (between 0.7 and $2.1 \%$ ) and represented selected roads, streets and tram lines, mainly reflecting the vicinity of the respondent's place of residence or study (e.g. names of the streets adjacent to the school or home).

Nodes on the mental maps represent Szczecin's roundabouts which, in spite of their shape and obvious traffic organisation, are in many cases called squares. Szczecin has 41 roundabouts. The three most recognisable ones are squares referring to the three stars in the constellation of Orion: Plac Szarych Szeregów, Plac Odrodzenia and Plac Grunwaldzki. For this reason, Szczecin is also called "the city of Orion". However, this oddity of the city was included in only $6.4 \%$ of the mental maps, which can be explained by the respondents' average age (17), unawareness of that fact and lack of experience in passing through such junctions as drivers. The most frequently chosen nodes included Plac Grunwaldzki (9.5\%), Plac Rodła (8\%), Plac Kościuszki (6.3\%) and Plac Szarych Szeregów (6.3\%) (Figure 2). In individual cases, five other roundabouts appeared on the maps: Plac Lotników, Plac Odrodzenia, Rondo Hakena, Rondo Ofiar Katastrofy Smoleńskiej and Rondo im. Ks. Lucjana Gierosa.

${ }^{1}$ The centre of Szczecin is shown separately due to the number of elements on the mental maps. 


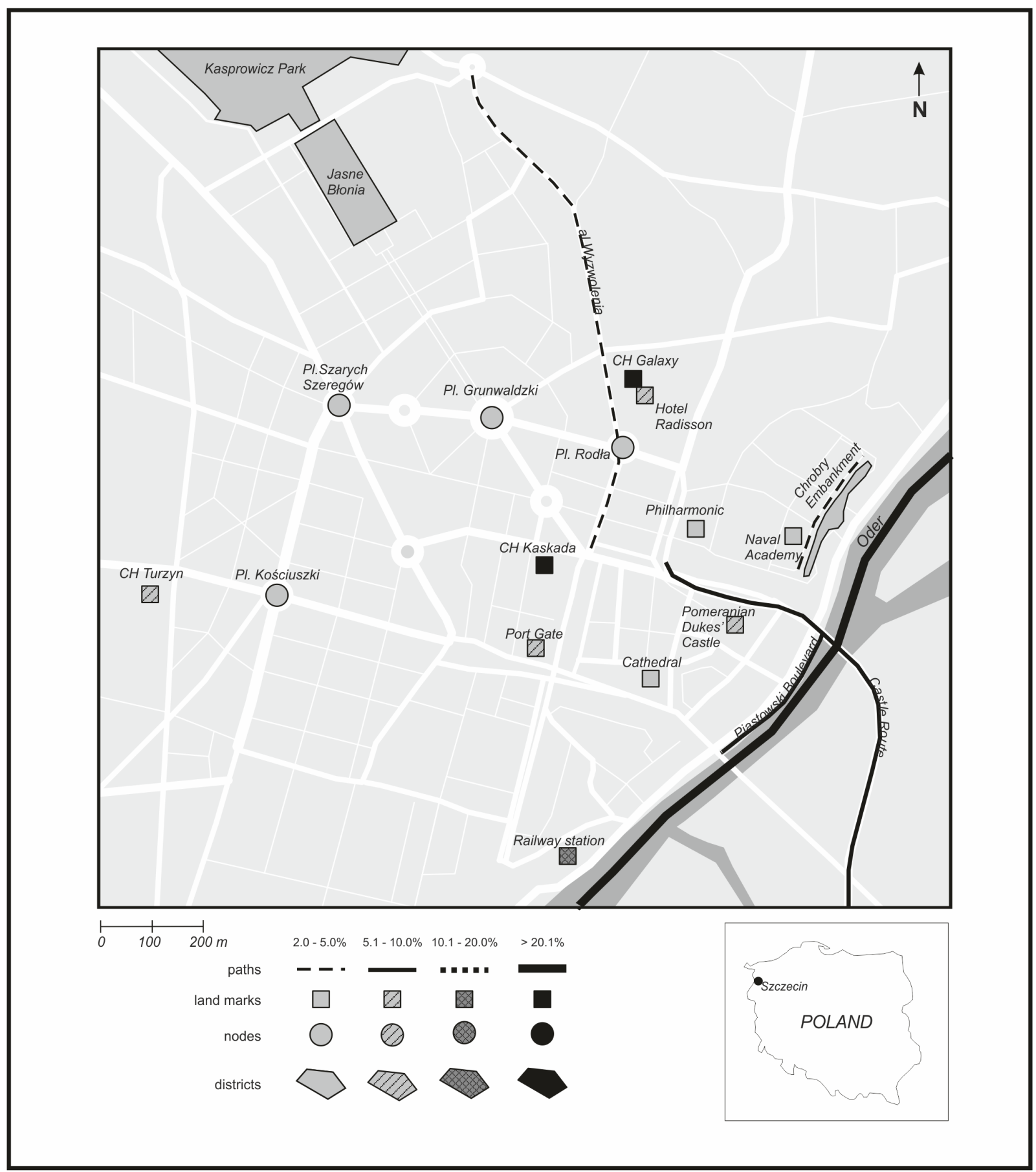

Figure 2. Szczecin city centre on mental maps. ${ }^{2}$ Source: Prepared by the authors based on the study conducted

Edges on mental maps are linear elements. In research, they are considered boundaries, or elements organising the space studied. In the presented study, the edges were either the subjective boundaries of Szczecin - the line organising the city into one whole - or objective barriers like the Oder River. In the first case, Szczecin as an area with marked city limits appeared in $20 \%$ of the mental maps. The perception of Szczecin in the context of its administrative division is very interesting. Szczecin is divided into four districts: Prawobrzeże (the Right Bank Szczecin's largest district on the right bank of the Oder; as such, it did not appear on any of the maps) and three districts on the left bank: Północ (North), Zachód (West) and Śródmieście (City Centre), recognised on $5 \%$ of the maps. Szczecin was presented as a whole, including the right and the left banks of the Oder, on $38 \%$ of the mental maps. However, the majority of respondents (44\%) perceived Szczecin as a city located only on the left bank of the Oder. In such cases, the Oder was a side reference, the city's edge. The left-bank part of the city was regarded by many respondents as the proper city of Szczecin, "the city", the good side or the modern side. Prawobrzeże was presented rather 


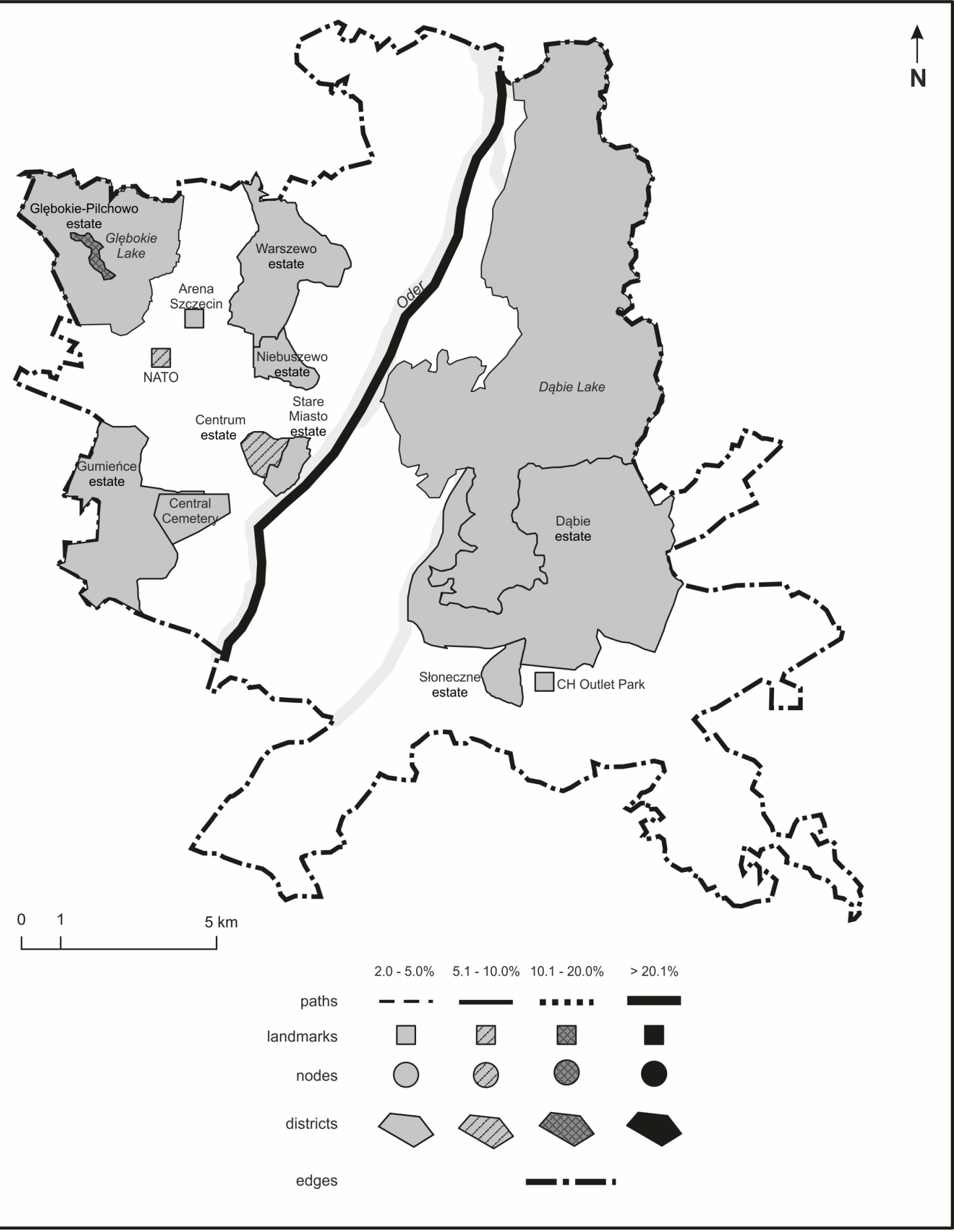

Figure 3. Synthetic mental map of Szczecin. Source: Prepared by the authors based on the performed study

negatively on $11.5 \%$ of the mental maps. In $4.3 \%$ of cases, it was a place where only the Outlet Shopping Centre (Figure 3 ) or another single facility (a furniture shop, the Concert Hall) is located. On few maps ( $7 \%$ in total) we found opinions that Prawobrzeże is a bad, criminal, industrial or unknown side, or that it is the other side of the city that features a forest only, a part of the city that the mayor is not concerned about, or that Prawobrzeże is not a district of Szczecin at all. The majority of such opinions on Prawobrzeże appeared on the mental maps drawn by the international group of students who do not inhabit this part of the city. In their opinion, Prawobrzeże is a great unknown, a shopping area with one of Szczecin's shopping centres (Outlet) or the exit from the city to the motorway.

Another important element of mental maps are functional areas or districts. In our study, the districts were mainly housing estates. The above-mentioned districts of Szczecin comprise 
37 estates: 26 estates in the Północ, Zachód and Śródmieście districts, and 11 estates in Prawobrzeże. The estates that were most frequently drawn on the mental maps were Centrum $(9.3 \%)$, Stare Miasto (4.3\%), Dąbie (3.6\%), Warszewo (2.8\%), Słoneczne (2.8\%), Głębokie-Pilchowo (2.1\%) and Gumieńce (2.1\%). Other estates appeared in a few sketches (Figure 3). In total, 21 of the 37 estates of Szczecin appeared on the mental maps. Only $14.3 \%$ of the respondents drew the estates as functional areas. In addition, $14.3 \%$ of the maps featured only the estate names and showed no attempts whatsoever to draw boundaries of the areas. The low popularity of housing estates on the maps supports the previously made assumptions that students perceive the urban space in two categories only: as the city centre where the most important (in the respondents' opinion) facilities are located, and as places of residence which are in some cases situated outside the administrative city limits. Villages near Szczecin, for example Bezrzecze (2.8\%), Mierzyn (2.8\%) or Dobra (2.1\%) appeared as functional areas on $8.5 \%$ of the mental maps.

The other most frequently drawn functional areas were recreational areas, such as Głębokie Lake $(10.7 \%)$ and Dąbie Lake (4.3\%); forests, namely Las Arkoński (2.8\%) and Puszcza Bukowa (1.4\%); as well as Jasne Błonia, a popular wide green square in the city centre $(7.8 \%)$; the Szczecin Terrace (5\%); the Kasprowicz Park (2.8\%); and Poland's largest Central Cemetery $(4.3 \%)$. Other surface elements that occasionally appeared on the maps include allotments, car parks and playgrounds.

According to the students, the most popular landmarks in the image of Szczecin are shopping centres, because two of them, Galaxy and Kaskada, achieved the best results: $43.6 \%$ and $39.3 \%$, respectively (Figure 2). However, such good results are to be explained by the location of the landmarks in the very centre of the city. Apart from those two mentioned above, other main shopping centres of Szczecin also appeared on the maps: Turzyn (8\%), Ster (5\%), Outlet Park (3.6\%) and Atrium Molo (0.7\%).

School $(42.1 \%)$ and home $(21 \%)$ were obvious landmarks on the mental maps of students. It seems that the space of everyday existence is based mainly on these two elements, complemented by a shopping centre visited on occasion (mainly at weekends). The list lacks cultural, sports and leisure facilities, or even family or friends' places of residence, which should be regarded as worrying. This confirms the increasingly popular consumer lifestyle and the attitudes of alienation towards the environment.

Communication infrastructure facilities, including railway stations $(13.6 \%)$, tram stops $(4.3 \%)$ and roundabouts $(3.6 \%)$, as well as social infrastructure facilities, were frequent landmarks on the mental maps. Among the latter facilities, Multinational Corps Northeast $(7.1 \%)$, part of NATO's armed forces, was the most popular. This was due to the fact that $\mathrm{MNC} \mathrm{NE}^{2}$ was the workplace of the parents of some of the surveyed students (Figure 3 ).

Places associated with history, culture or recreation turned out to be less important landmarks. Szczecin's well-known monuments and architecture elements (Kozińska 2010) appeared on the mental maps only occasionally, e.g. the Ducal Castle $(5.7 \%)$, the Harbour Gate $(5.7 \%)$, the Cathedral Basilica of St James the Apostle (4.3\%) and the Szczecin Philharmonic (3.6\%) (Figure 2). The above results lead to the following conclusions:

1. The image of the city as seen by Szczecin's students is very simplified. This is not always due to the stage of their intellectual development but may also result from the lifestyles and attitudes to life cultivated by their parents or guardians.

2. The majority of students are not aware of the city's size, shape and internal layout, which seems to be fairly surprising in the light of their geographical education.

${ }^{2}$ Multinational Corps Northeast (https://mncne.pl)
3. A considerable number of the mental maps were created on a very general level, without any details. This may be due to the students' passive attitude and lack of skills or, what is worse, spatial orientation inability.

4. The students made poor use of the sheet (A4) to draw the maps, which is puzzling. Their inability to plan out, scale, generalise and orient the map as a whole is apparent.

5. Some of the students have a clear problem with presenting the space graphically and tried to mask the problem (perhaps also their laziness) by using text. There were cases of mental maps being in fact text maps.

The image of Szczecin in the research surveys

The respondents answered the question about their first association with Szczecin. Their answers were grouped according to the most frequent associations and were assigned proper names, e.g. buildings, maritime character of the city, etc. Associations gathered under the designation of "other" include single phrases, family connections or private life events mentioned by the respondents, i.e. those which cannot be assigned to any of the proposed groups. The largest group of responses are associations with material objects, referred to in this study as "buildings", related to places of residence, work and leisure as well as characteristic landmarks on the city map. The maritime character of the city primarily manifests itself in the presence of the Oder River, the harbour, the shipyard and ships near the river as well as regattas in the summertime. The respondents appreciated the group of regional products defined not only as physical goods and products of the food industry but also as an organisation (a locally active sports club). The category of city aesthetics included mainly adjectival designations of the city landscape, which in many cases were mutually exclusive and had mostly negative overtones. In addition, the students took into account the weather conditions in Szczecin, mostly referring to bad weather. The answers provided in this regard were due to the season during which the survey was conducted (Table 1).

The next questions concerned the assessment of the city of Szczecin as a place that is friendly to foreigners. The majority of opinions $(62 \%)$, received predominantly from the Poles, were positive. The respondents justified their answers by pointing out that there is a wide variety of attractions for foreigners, there are leaflets and information available in foreign languages, as well as schools and courses for foreigners, student exchanges, a broad multisector labour market and tolerant inhabitants who have a good command of foreign languages, resulting from living in the borderland and from employers' stringent requirements.

The foreigners perceive the situation differently. Negative opinions were expressed by $34 \%$ of the respondents, mainly the foreigners. In their opinion, the biggest problem hindering easy orientation in the city (public transport, communications in public places) is the lack of (paper, electronic, visual, etc.) information in their languages. They also have trouble with intolerant inhabitants.

Foreign inhabitants of Szczecin travel most frequently by car $(62 \%)$, by tram $(25 \%)$ or by bus $(7 \%)$. The Poles do otherwise; they mostly use public transport to commute - by tram $(40 \%)$ and by bus (35\%). Private cars are used by $22 \%$ of the Polish inhabitants.

The respondents share their free time between outdoor activity in the bosom of nature and indoor activity in sports and entertainment facilities. The Polish and foreign respondents choose the same places for recreational activities in the open air. Their favourite places of leisure are the boulevards at the Oder, Jasne Błonia, Kasprowicz Park, Szczecin Terrace, Lake Głębokie, Arkoński Park Leśny (Arkona Forest Park) and Puszcza Bukowa (Beech Forest). These are the most representative places of 
Table 1. Percentage structure of answers to the question about the first association with Szczecin.

\begin{tabular}{|c|c|c|}
\hline Proper name & Associations & $\%$ \\
\hline buildings & $\begin{array}{r}\text { Szczecin Terrace, NATO's corps barracks, home, boulevards, Galaxy } \\
\text { shopping centre, school, Castle Route, Ducal Castle }\end{array}$ & 25 \\
\hline maritime character of the city & $\begin{array}{c}\text { Oder River, harbour, sea, ships, shipyard, water, sea wolves, regattas } \\
\text { (canned fish spread) }\end{array}$ & 17 \\
\hline regional products & $\begin{array}{c}\text { Pogoń Football Club, patties, Bosman Brewery, paprykarz szczeciński } \\
\text { city aesthetics }\end{array}$ & \begin{tabular}{c} 
cold, cloudy, rainy, windy \\
\hline climate
\end{tabular} \\
\hline location & proximity to Germany, large, small & 4 \\
\hline other & slogans like: Lecim na Szczecin! [Let's fly to Szczecin!], the city of Orion & 28 \\
\hline
\end{tabular}

Source: Prepared by the authors based on the questionnaire survey.

recreation within the city limits of Szczecin. The same is true for indoor places. The Galaxy and Kaskada shopping centres were unrivalled in the survey ( 31 and $21 \%$, respectively) due to the attractiveness of their catering outlets, amusement arcades, cultural facilities (cinemas) and clothing shops. The respondents' choice of shopping centre does not correlate with their place of residence.

The questionnaire survey also addressed the issue of places avoided by young people. The foreigners did not indicate any particular places or areas but rather limited themselves to providing adjectival expressions like dark streets, unknown streets, parks or passageways between blocks of flats. At the same time, the Poles unanimously found the Niebuszewo residential estate, Parkowa Street and the post-industrial Skolwin and Gocław estates, stretching along the Oder in a northerly direction, to be dangerous at any time of the day and night. Those estates are inhabited by multigenerational families, poorly qualified and unemployed workers. The growing social pathology is intensified by the influx of people forcibly resettled as part of Szczecin's housing resource management. A large group of the respondents are not afraid of anything and do not consciously avoid any places.

In another thread of the survey, the respondents answered the question as to whether it is possible to practise different forms of sports and recreation in the city. Amongst the wide range of facilities and attractions, of which $16 \%$ of the respondents were aware, a water park $(14 \%)$ and a theme park $(11 \%)$ were missed most by the largest group of respondents. The foreigners complained that there are no amateur football or gymnastic clubs for English speakers. The Poles listed a whole range of "shortcomings", e.g. places helping to develop a passion for cooking or places for "manga and anime" fan conventions. In addition, they pointed out the lack of a zoological garden, forester's lodges or places where fashion shows could be organised.

The above messages may indirectly indicate the quality of life in the city of Szczecin as assessed by its young inhabitants. In this context, $70 \%$ of the respondents found the life in the city to be comfortable and in line with their expectations, principally because of living conditions that are close to those in other European cities, lack of earlier expectations, which significantly contributed to the lack of a negative attitude among foreign respondents, convenient location close to the Baltic Sea and to the State's western border. However, $30 \%$ of the respondents were not satisfied with the quality of life in the city, mainly due to the lack of their dream attractions dedicated to young people, and the inconvenience resulting from limited public transport accessibility.

\section{Discussion}

The dependence resulting from the age of the respondents and the number of depicted elements on the imaginary maps created by them was noticed. The younger the respondents (12 years), the fewer elements appear on their mental map. Mental maps of older students usually have more elements and details, which may result from their independence and individual exploration of the space, and, obviously, from the stage of their educational development (Figure 1). The spatial range of the maps, however, as in the case of younger students, is also narrowed down to the centre and places of residence. It seems that further stages of research should involve the role of age and other demographic characteristics in creating the image of the city.

The study has also proved that the nationality of the respondents affects the notion of Szczecin. The results of the survey indicate that the group of foreigners mainly moves around the city in their parents' cars, as opposed to Polish students who mostly use public transport, as indicated by the results of the surveys. This is reflected in their mental maps. Those who travel mainly by car drew more roads and suburban villages (often their places of residence) on their maps. On the other hand, the maps created by those travelling mainly by public transport included tram lines and stops as well as roundabouts. It can be thus assumed that the means of transport used has a significant impact on the notion of the city. The choice of the means of transport is sometimes connected with, inter alia, the time needed to reach a destination and this has a significant effect on the ability to remember even large elements of the urban structure. Furthermore, the use of public transport makes the user considerably more sensitive to external stimuli of travelling (urban traffic), compared to private cars, by which some students travel, staying, so to speak, in a family cocoon, often "from door to door".

Negative characterisation of the Prawobrzeże district is another feature that distinguishes the group of foreign students. Among the Polish respondents, on the other hand, the negative opinion was expressed about the Niebuszewo housing estate. It was considered a dangerous area by $11 \%$ of the respondents. 


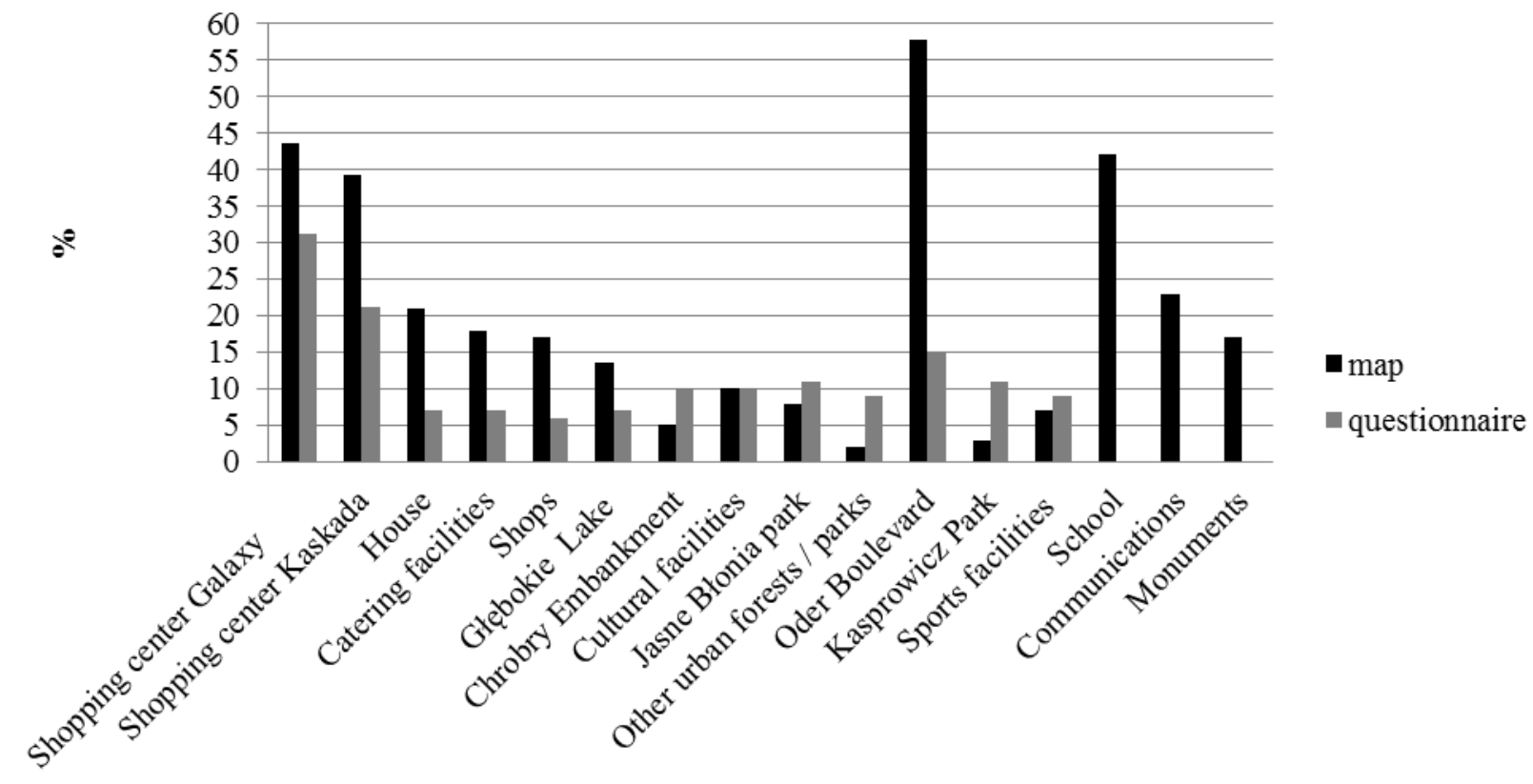

Figure 4. Relationship between the favoured places mentioned in the survey and the places marked on the mental maps. Source: Prepared by the authors based on the performed study.

Such negative stigmatisation of places could be the effect of a number of reasons, e.g. the lack of or inadequate knowledge of the place, or spreading knowledge that is often out of date and thus false, and can be considered a stereotype. It also appears that the significance of our own experience of urban exploration cannot be disregarded. The contemporary view of Niebuszewo as a dangerous and poorly lit estate is principally related to aesthetic reasons - the squalid or abandoned municipal infrastructure. It is worth noting that no one has indicated their place of residence and study as a dangerous place.

The comparative analysis of the survey's results and of the mental maps has confirmed, to some extent, their homogeneity and the coherence of the image of Szczecin (Figure 4). All the places indicated as favourite were included on the maps but also additional elements (features) appeared, i.e. those considered important to the respondents, e.g. school, home, single monuments or other landmarks. It is worth mentioning that the image of Szczecin as presented on the maps was $98 \%$ positive or neutral. Unpopular features that were indicated in the survey as those which should be avoided did not appear on the maps. Among the associations with the city indicated in the questionnaires, $36.4 \%$ were included on the maps.

\section{Conclusion}

Correct imagining of a space is one of the most desirable effects of learning about the closest environment. The things we perceive in the environment, what we are more or less sensitive to, depend on our priorities, and indirectly on the adopted assumptions, value systems, possessed knowledge and skills, demographic and socio-cultural characteristics such as age, gender, nationality, etc.
The assessment of the perception of Szczecin's urban area by its young inhabitants and the definition of the relationship between various elements of their imaginations largely confirmed the research assumptions. The obtained results indicate that age determines the detail of ideas about Szczecin. One can assume that the younger the respondents, the less detailed the mental map is. However, age does not affect the spatial extent of the presented content, which means that regardless of age, places that are related to the everyday existence of pupils are presented. It can therefore be assumed that there is a far-reaching spatial selectivity rather than the expected generalisation (reduction), especially among older students.

The form of transportation around the city has a significant impact on the image of the city. This, within the studied group, is related to the wealth of pupils, and indirectly to the nationality of the respondents, because foreign students usually use private transport, and Polish students mostly take public transport with all its consequences.

In parallel with the sketching studies carried out, surveys were carried out using the questionnaire method. The obtained results led to the conclusion that Szczecin's image on mental maps and in questionnaires is coherent, which is verified by a similar percentage of indications dominating in the landscape of the city elements.

A separate, but very important, conclusion is that regardless of the age of the respondents or their nationality, there are serious gaps in the geographic knowledge of students. They concern not only the knowledge of the nearest neighbourhood (region, district, city), but also the ability to orientate in space, to move around it and to draw up a sketch or plan. 
Błahut, G 2013, ,Mapy mentalne jako wyobrażenia miejskich obszarów kulturowych' ['Mental maps as imaginations of urban cultural areas'], Studia Etnologiczne i Antropologiczne, vol. 13, pp. 47-56.

Downs, RM \& Stea, D 1977, Maps in minds: Reflections on cognitive mapping, Harper \& Row, Publishers, New York.

Downs, RM \& Stea, D 1973, Image and environment: Cognitive mapping and spatial behaviour, Aldine, Chicago.

Gendźwiłł, A 2009, ,O prezentacji kartograficznej wyników badań map poznawczych Polski' ['On the cartographic presentation of the results of research on cognitive maps of Poland'], Przegląd Kartografczny, vol. 41, no. 2, pp. 115-127.

Graham, E 1976, 'What is a mental map?', Area, no. 9, pp. 259262.

Gregory, D, Johnston, R, Pratt, G, Watts, M \& Whatmore, S 2009, The Dictionary of Human Geography (5th edition), WileyBlackwell, United Kingdom.

Harvey, D 1973, Social justice and the city, London: Edward Arnold

Hauzinski, A 2011, Ewolucja pojęcia mapy poznawczej w psychologii i jej wykorzystanie w urbanistyce, architekturze oraz geografii [The evolution of the concept of cognitive map in psychology and its use in urban planning, architecture and geography]. Available from: <https://www.researchgate.net/ publication/284435076>. [7 November 2018].

Kaplan, S 1973, 'Cognitive maps, human needs and the designed environment' in Environmental design research, vol. 1, ed. WFE Preiser, pp. 275-283.

Kozińska, B, Słomiński, M \& Solecki, G 2010, Szczecin. Praktyczny Przewodnik Turystyczny [Szczecin. Practical Travel Guide], Walkowska Wydawnictwo JEŻ, Szczecin.

Kuipers, B 1982, 'The „Map in the Head” Metaphor', Environment and Behavior, vol. 14, no. 2, pp. 202-220.

Kitchin, R 1994, 'Cognitive maps: what they are and why study them', Journal of Environmental Psychology, vol. 14, pp. $1-19$.

Kozłowski, K \& Krzywicki, S 1988, Historyczna droga do polskiego Szczecina [A historic road to Polish Szczecin], Krajowa Agencja Wydawnicza. Szczecin.

Ley, D 2000, 'Mental maps', in The Dictionary of Human Geography, (4th edition), eds. RJ Johnston, D Gregory, G Pratt G \& M Watts, Blackwell Publishers, United Kingdom, pp. 498-499.

Lisowski, A 2003, Koncepcja przestrzeni w geografii człowieka [The concept of space in human geography], Wydział Geografii i Studiów Regionalnych UW, Warszawa.

Liszewski, S2005, ,Przestrzeń turystyczna w ujęciu podmiotowym. Przyczynek do dyskusji w przestrzeni w geografii' ['Tourist space in terms of subject. A contribution to the discussion in space in geography'] in Geografia, jako nauka o przestrzeni, środowisku i krajobrazie, eds W Maik, K Rembowska \& A Suliborski, Łódzkie Towarzystwo Naukowe, Łódź, pp. 50-60. Lynch, K 1960, The image of the City, MIT Press, Cambridge.

Marshall, B 2017, 'Mapping the geology of Northland. New Zealand geological survey bulletin, no.8, (Whangaroa Subdivision)', The Globe, no. 82, pp. 26-46.

Multinational Corps Northeast 2018. Available from: <https:// mncne.pl>. [7 November 2018].

Nawrocki, T 2015, Wykorzystanie map mentalnych $w$ badaniach przestrzeni publicznych. Przykład Gliwic. [The use of mental maps in the study of public spaces. Gliwice example.] Available from: <https://www.researchgate.net/ publication/296974325>. [7 November 2018].
Punch, K 2005, Introduction to social research, quantitative and qualitative approaches, Second edition, London, Sage Publications Ltd.

Szczecin. Raport o stanie miasta 2014 [Szczecin. Report on the state of the city 2014]. Available from: <http://bip. um.szczecin.pl/UMSzczecinFiles/file/Raport_o_stanie_ Miasta_2014.pdf>. [7 November 2018].

Tolman, EC 1948, 'Cognitive maps in rats and men', Psychological Review, vol. 55, pp. 189-208.

Tolman, EC 1995, Zachowanie celowe u zwierząt i ludzi [Specific behavior in animals and people], WN PWN, Warszawa.

Tuan, Y 1975, 'Images and mental maps', Annals of the Association of American Geographers, vol. 65.2, pp. 205212. 